\title{
Structure and Functional Effect of Tryptophan Mutants of Nicotiana tabacum Acetohydroxyacid Synthase
}

\author{
Im-Joung La, Masud Karim, and Moon-Young Yoon* \\ Department of Chemistry, Hanvang Lnversity, Seoul 133-791, Korea. ${ }^{\star}$ E-mail: myoonahantang.ackr \\ Received June 23, 2008
}

Key Words : Açetohỵdrox̦̦acid șynthase. Circular dichroișm. Tryptophan quenching. Herbicide inhibition

The branched chain amino acids (BCAAs) are synthesized by plants, algae, fungi, bacteria and archaea. but not by animals. Therefore the enzymes of the BCAA biosynthetic pathway are potential targets for the development of herbicides, fungicides and antimicrobial compounds. Most interest has focused on the first enzyme in this pathway. acetohydroxyacid synthase (AHAS. EC 2.2.16) because it is the target of several herbicides including the sulfonylureas (SUs), ${ }^{3}$ inidazolinones (IMs). ${ }^{2}$ triazolopyrimidines ${ }^{3}$ and pyri-nidinyl oxybenzoates. ${ }^{+5}$ AHAS catalyzes the condensation of two molecules of pyruvate to give rise to 2-acetolactate in the first step of valine and leucine biosynthesis. and in parallel. it also catalyzes the condensation of pyruvate and 2-ketobutyrate to yield 2-aceto-2-hydroxybutyrate in the second step of isoleucine biosynthesis. ${ }^{6}$ AHAS requires thiamine diphosphate (TlDP). flavin adenine dinucleotide (FAD). and a divalent metal ion. $\mathrm{Mg}^{2+}$ or $\mathrm{Mn}^{2-}$, as cofactors for its catalytic function.

In the past, research on plant AHAS has been hindered due to its instability and low abundance in plants. The AHAS genes from Arabidopsis thalicma ${ }^{7}$ and tobacco ${ }^{8}$ have been functionally expressed in E coli and purified as glutathione S-transferase fusion proteins. Recently, we have reported several herbicide-resistant mutants of tobacco AHAS $^{(5)}$ and also identified the role of lysine. ${ }^{11}$ arginine. ${ }^{11}$ histidine, ${ }^{12}$ methionine. ${ }^{13}$ aspartic acid ${ }^{1+4}$ and tryptophan residues. ${ }^{15}$ The inhibition effect of herbicides was also characterized for several AHAS sources. ${ }^{1 \leqslant .17}$ In the tobacco AHAS two tryptophan residues (W573 and W490) were reported as critical for enzyme activity. ${ }^{18}$ The yeast crystal model suggests that the pyrimidine ring of ThDP would stack on the indole ring of W586 (W573 in tobacco). ${ }^{19}$ Within the $\gamma$-domain of AHAS three tryptophan residues were identified (W490. W503, and W573) which could potentially participate in hydrophobic stacking interactions.

To determine the catalytic role of tryptophan residues (W266. W439. W490, W503 and W573) in tobacco AHAS. we carried out site-directed nutagenesis in this study. The effect of the mutations on the kinetic parameters. cofactor binding, structure of the enzyme and inhibition by herbicides were analyzed.

All mutants were expressed and successfully purified to homogeneity. SDS-PAGE analysis showed that all mutants had the same molecular mass as that of wild type enzyme (data not shown). The ability of wild type and tryptophan mutant proteins to produce acetolactate in the absence of 2ketobutyrate was measured and the results are shown in Table l. The acetolactate formation also serves as an indirect measure of the affinity of the wild type and various mutant proteins for the substrate. The kinetic parameters were obtained by analysis of Michaelis-Menten plots of initial rates for AHAS under standard cofactor conditions. Among the five tryptophan mutants. the W573F showed a 30 -fold reduction in enzyme activity whereas $\mathrm{W} 490 \mathrm{~F}$ had completely abolished the enzyme activity. The $K_{n}$ value for $\mathrm{W} 573 \mathrm{~F}$ was approximately 25 -fold higher than that of wild type, indicating the perturbation of the substrate binding site. The kinetic parameters of W503F, W266F and W439F were not significantly altered relative to those of wild type. These data indicate that W490 and W573 are the most important catalytic tryptophan residues involved in the catalysis. The results were identical with previous reports by Chong et $a{ }^{18}$

The cofactors-dependent quenching of intrinsic protein fluorescence leads to a reduction in equilibrium fluorescence and is a measure of the cofactors binding affinity to AHAS. Molecular modeling studies of the $\gamma$-domain intermediate complex revealed that W573 is largely buried within the structure in a nonpolar pocket and W490 is also in a largely nonpolar region sandwiched between helices within the $\beta$ domain. To investigate the function of these two tryptophan residues (W490 and W573), fluorescence quenching studies were carried out with varying ThDP concentrations. The quenching of tryptophan fluorescence provides a direct tool for the determination of the dissociation constant of a protein-ligand complex. However. the sensitivity of the method depends on the number and location of the fluorophores.

Table 1. Kinetic parameters and $\mathrm{IC}_{50}$ values of wild type AHAS and tryptophan mutants

\begin{tabular}{|c|c|c|c|c|c|}
\hline \multirow[b]{2}{*}{ Enzyme } & \multirow{2}{*}{$\begin{array}{c}K_{\mathrm{m}} \text { for } \\
\text { pyruvate } \\
\text { (mM) }\end{array}$} & \multirow[b]{2}{*}{$\begin{array}{c}I_{\text {tmax }} \\
(\mathrm{U} / \mathrm{mg})\end{array}$} & \multicolumn{3}{|c|}{ IC so value for sulfonylureas } \\
\hline & & & $\begin{array}{l}\mathrm{SMM} \\
(\mathrm{nM})\end{array}$ & $\begin{array}{c}\mathrm{CE} \\
(\mathrm{nM})\end{array}$ & $\begin{array}{l}\text { PSM } \\
(\mathrm{nM})\end{array}$ \\
\hline Wild & 14.7 & 6.47 & $2.31 \pm 0.42$ & $6.12 \pm 0.73$ & $5.46 \pm 0.21$ \\
\hline W266F & 45.6 & 8.11 & $3.45 \pm 0.51$ & $4.23 \pm 0.22$ & $7.34 \pm 0.71$ \\
\hline W439F & 25.17 & 5.66 & $4.35 \pm 0.21$ & $8.16 \pm 0.26$ & $4.68 \pm 0.64$ \\
\hline W490F & NA & $\mathrm{NA}$ & $\mathrm{NA}$ & NA & $\mathrm{NA}$ \\
\hline W503F & 53.22 & 4.65 & $3.56 \pm 0.61$ & $27.05 \pm 0.28$ & $9.45 \pm 0.13$ \\
\hline W573F & 424.27 & 1.31 & $87.1 \pm 0.23$ & $73.32 \pm 0.45$ & $68.17 \pm 0.82$ \\
\hline
\end{tabular}

NA: No enzymatic activity 
Tobacco AHAS exhibited untrinsic fluorescence characteristics due to the presence of tryptophan residues, very likely burled in the protein, as revealed by a low fluorescence enussion maximum $(340-345 \mathrm{~nm})$ upon excitation at 300 $\mathrm{lm}$. ${ }^{3 i}$ Replacement of each of the three tryptophan residues within the catalytic domain followed by titration with ThDP revealed that substitution of both W490 and W573 residues alleviated the substrate-induced fluorescence quenching (data not shown). In order to further investigate this quenching mechanism, ttration of a number of tryptophan replacement mutant proteins with ThDP was conducted. When W573 was replaced with phenylalanine in the AHAS protein's active site, the alleviation of the observed quenching upon ThDP binding was the largest among the mutant proteins tested. The largest effect was observed upon substitution of W573 (a change from $42 \%$ to $25 \%$ quenching). ${ }^{21}$ The reduction in the fluorescence quenching was smaller but significant for the $\mathrm{W} 490 \mathrm{~F}$ mutant $(42 \%$ to $36 \%$ quenching: Figure 1), whereas W266F, W439F and W503F had quench-
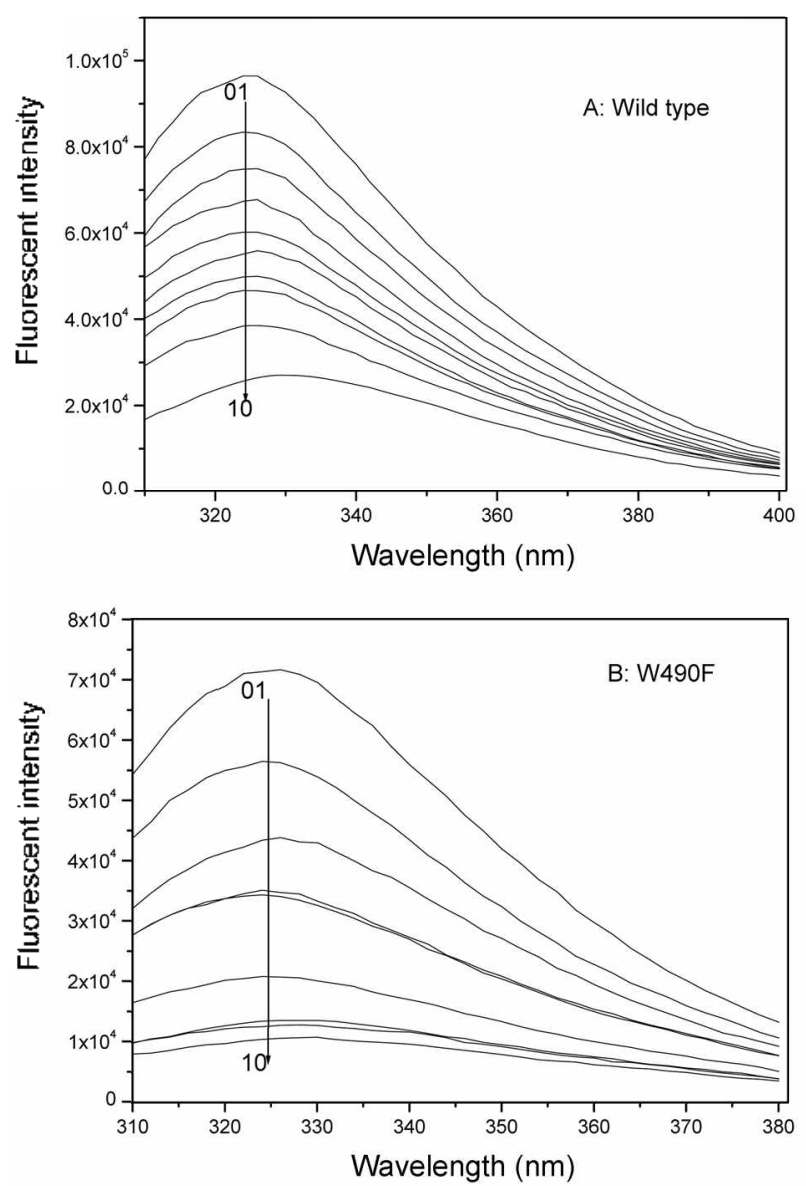

Figure 1. The effect of $\mathrm{ThDP}$ on the fluorescence emission spectrum of wild type and mutant AHAS (W490F). Each $0.1 \mathrm{mg} /$ mL of wild type AHAS (A) and the same concentration of W490F (B) encyme was pre-incubated with a buffer containing $100 \mathrm{mM}$ potassium phosphate buffer $\mathrm{pH} 7.4,20 \mu \mathrm{M}$ FAD, $2 \mathrm{mM} \mathrm{MgCl}$, and the following indicated concentrations of ThDP were added. 0 (1), 0.06 (2),0.1 (3), 0.12(4),0.2(5),0.25(6),0.4(7),0.5(8),0.8 (9) and $1.0(10) \mathrm{mLM}$ (the curve numbers were indicated through an anow from 01 to 10 ). The wavelength of excitation was $300 \mathrm{~nm}$ and the emission spectra were recorded in the range $310-450 \mathrm{~nm}$. ing simular to the wild type protein (data not shown). The dissociation constants were determined by fitting the data to Equation (1) where $F_{0}$ is the intrinsic fluorescence of enzyme in the absence of quencher. $F_{1}$ is the observed fluorescence at a given $[Q]$ (concentration of quencher). $f_{a}$ is the fractional degree of fluorescence and $K_{d}$ is the dissociation constant.

$$
\left(1-\frac{F_{1}}{F_{i j}}\right)=\frac{f_{d r} \cdot[Q]}{K_{d}+[Q]}
$$

Fluorescence quencling of $\mathrm{W} 490 \mathrm{~F}$ and $\mathrm{W} 573 \mathrm{~F}^{21}$ by ThDP gives dissociation constants $\left(K_{d}\right)$ of $0.54 \pm 0.01 \mathrm{mM}$ and $0.40 \pm 0.01 \mathrm{mM}$ respectively. values that are virtually identical with wild type protein $K_{a}=0.34 \mathrm{mM}$. These results unply that the ThDP binding itself into a deep channel of the active site was not affected by the single mutations (W573F or $\mathrm{W} 490 \mathrm{~F}$ ). The titration and intrinsic fluorescence quenching of W573F by pyruvate imply that pyruvate binding in the active site was not affected by the substitution at position $573 .^{21}$ The absorption and fluorescence emission peaks of $\mathrm{W} 490 \mathrm{~F}$ corresponding to the cofactor FAD indicated that the W490F mutation prevents this cofactor binding to AHAS with a consequent loss of enzymatic activity. ${ }^{18}$ Thus. W490 likely plays an indirect role in the catalytic mechanism of the enzyme. possibly in maintaining the active site integrity However. the $K_{m}$ value of the W573F mutant was 30 -fold higher that that of wild type. suggesting that W573 may play a major role in the formation of enzyme-substrate or enzyme bound intermediate complex. These results imply that W573 plays only an indirect role in cofactor binding. likely acting as an anchor that stabilizes the loop containing M569 which packs against the pyridme ring of ThDP.

In order to determine whether the mutations induced any secondary structural alterations in the enzyme. the CD spectra of the wild type and mutants were recorded in the far-UV regions. The $W 573 \mathrm{~F}$ showed slight differences in the far-UV region. whereas other mutants were similar to that of

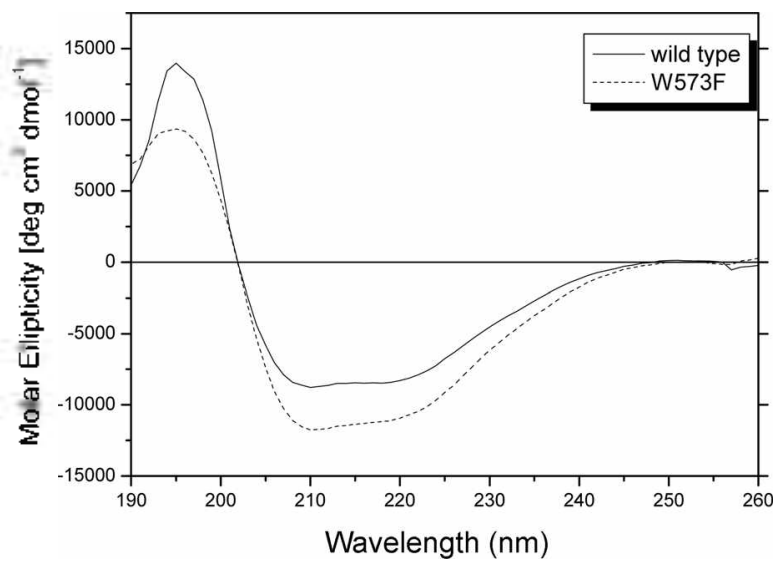

Figure 2. Far-UV CD spectra of the wild type (solid line) and W573F (dotted line) mutant enzymes. Each protein was present at a concentration of $0.20 \mathrm{mg} / \mathrm{mL}$ in $10 \mathrm{mM}$ potassium phosphate buffer (pH 7.5). The secondary structural components were determined by fintting the data to an algorithm, the conves constraint analysis (C.CA) ${ }^{24}$ 
Table 2. Secondary structure of wild type and W573F AHAS calculated from CD analysis

\begin{tabular}{lccccc}
\hline Protein & $\begin{array}{c}\alpha \text {-Helix } \\
(\%)\end{array}$ & $\begin{array}{c}\beta \text {-Sheet } \\
(\%)\end{array}$ & $\begin{array}{c}\text { Random } \\
(\%)\end{array}$ & $\begin{array}{c}\text { Tun } \\
(\%)\end{array}$ & RMS \\
\hline Wild type & 27.3 & 41.8 & 18.3 & 12.6 & 9.645 \\
W573F & 38.1 & 0.0 & 32.3 & 29.6 & 13.53 \\
\hline
\end{tabular}

wild type enzyme (Figure 2 and data not shown). The secondary structural components were determined for both wild type and W573F mutant (Table 2) by fitting the data to an algorithm. the convex constraint analysis (CCA). However. no significant secondary structural changes were detected in the W573F except for increases in $\alpha$-helix and random conformations with the disappearance of $\beta$-sheets (Table 2).

Earlier. Chong et al. reported that the W573F nutant of tobacco AHAS was reported as a sulfony lurea and triazolopyrinidine resistant form. ${ }^{18}$ This tryptophan residue was also responsible for herbicide resistance in veast $\mathrm{AHAS}^{23}$ Arabidopsis thatiana $\mathrm{AHAS}^{24}$ and $E$. coli AHAS II with a greatly decreased preference for 2-ketobutyrate as the second substrate. To date this, both wild type and mutant proteins were tested for resistance against three potent sulfonylurea herbicides (SMM, CE and PSM). The 50\% inhibition concentrations ( $\mathrm{IC}_{50}$ ) were analyzed by fitting the data to Equation (2).

$$
v=\frac{\left(V_{0}-V_{f}\right) \cdot I C_{50}}{I C_{50}+[I]}+V_{f}
$$

In this equation $V_{0}$ is the reaction rate without inhibitor. $V_{f}$ is the rate at maximal inlibition and [ $[$ is an inhibitor concentration. These results indicate that mutants W266F. $\mathrm{W} 439 \mathrm{~F}$ and $\mathrm{W} 503 \mathrm{~F}$ showed similar inhibition patterns to wild type and the inhibition effect was not determined for W490F (Table 1). However the W573F showed approximately 20 - to 30 -fold increase in $\mathrm{IC}_{50}$ values with all sulfonylureas tested. The significant increase in $\mathrm{IC}_{5 i}$ values for three potent sulfonylurea herbicides (SMM. CE and PSM) suggests that W573F has a major role in sulfonylurea herbicides binding site and in substrate recognition.

In conclusion, the present results suggest that W490 residue is likely located at or near the cofactor $\mathrm{FAD}$ binding site and may affect the binding affinity of FAD. ${ }^{\text {ss }}$ while the W573 residue plays only an indirect role in cofactor binding but plays a role in substrate recognition and process a common binding site for the sulfonylurea classes of herbicides. The W573F mutant appears to be a good candidate for the development of herbicide resistant transgenic plants.

\section{Experimental Section}

Site-directed mutagenesis of tobacco AHAS was performed directly on the plasmid derived from pGEX-2T containing tobacco AHAS cDNA using the PCR mega primer method. All manipulations of primers and DNA were carried out using the techniques reported previously. ${ }^{18}$

Bacterial strains of $E$. coli BL2l-DE3 cells, containing the expression vector pGEX-AHAS, were grown at $37^{\circ} \mathrm{C}$ in Luria-Bertani (LB) broth medium containing $50 \mu \mathrm{g} / \mathrm{mL}$ ampicillin to an $\mathrm{OD}_{\text {ou }}$ of 0.7-0.8. Expression of the pGEXAHAS gene was induced by the addition of $1 \mathrm{mM}$ isopropyld-thiogalactoside (IPTG). Cells were grown for an additional $16 \mathrm{~h}$ at $18^{\circ} \mathrm{C}$ and harvested by centrifugation at $5000 \mathrm{~g}$ for $30 \mathrm{~min}$. Purification of wild type and mutant AHAS were carried out as described previously by Chang et $a{ }^{36}$

Enzyme activities of the wild type and mutant AHAS were measured according to the method of Westerfeld with a modification as reported previously ${ }^{27}$ The reactions were carried out in standard reaction mixture containing $100 \mathrm{mM}$ potassium phosphate buffer $\mathrm{pH} 7.5$. 1 $\mathrm{mM}$ ThDP, $10 \mathrm{mM}$ $\mathrm{MgCl}_{2} .20 \mu \mathrm{M} \mathrm{FAD}$, and $75 \mathrm{mM}$ pyruvate. Different concentrations of herbicides were added to determine the inhibition effect. Assays were initiated by the addition of AHAS at $37^{\circ} \mathrm{C}$ for $30 \mathrm{~min}$ and terminated by the addition of $6 \mathrm{~N} \mathrm{H}_{2} \mathrm{SO}_{4}$. The reaction product acetohydroxyacid was allowed to decarbosylate at $60^{\circ} \mathrm{C}$ for $15 \mathrm{~min}$. The acetoin formed by acidification was incubated and colorized with $0.5 \%$ creatine and $5 \% \alpha$-naphthol at $60{ }^{\circ} \mathrm{C}$ for $15 \mathrm{~min}$. The absorbance of the reaction mixture was monitored at 525 num. One unit (U) of activity was defined as the amount of enzyme required for the production of $\mathrm{l} \mu \mathrm{M}$ of acetohydroxyacid per minute under the standard assay conditions described above.

The extent of ThDP binding was measured by monitoring the quenching of intrinsic fluorescence of the enzyme after addition of varying concentrations of ThDP. The purified enzymes $(0.1 \mathrm{mg} / \mathrm{mL})$ were pre-incubated in buffer containing $100 \mathrm{mM}$ phosphate buffer $\mathrm{pH} 7.4,20 \mu \mathrm{M}$ FAD. $2 \mathrm{mM}$ $\mathrm{MgCl}_{2}$ and the indicated concentrations of ThDP at $37^{\circ} \mathrm{C}$ for $15 \mathrm{~min}$. The wavelength of excitation was $300 \mathrm{~cm}$ and the emission was recorded in the range of $310-450 \mathrm{~mm}$ (bandwidth of $2 \mathrm{~nm}$ ) in a computer-controlled PTI Alphascan2 spectrofluorometer (Photon Technology Inc.. South Brunswick. NJ). Each emission value was the mean of three independent experiments. The far-UV CD spectrum was obtained on a Jasco J-715 spectropolarimeter using $0.1-\mathrm{cm}$ pathlength cuvettes at $25^{\circ} \mathrm{C}$. The samples were prepared in $10 \mathrm{mM}$ sodium phosphate $\mathrm{pH} 7.4$ and the protein concentration was $0.1-0.2 \mathrm{mg} / \mathrm{mL}$. A minimum of four spectra were accumulated for each sample and the contribution of the buffer was always subtracted. The secondary structural conponents from the CD spectra were analyzed by the new algorithm. the convex constraint analy sis (CCA)

Acknowledgments. This work was supported by the research fund of Hanyang University (HY-2007-I).

\section{References}

1. LaRossa, R. A.; Schloss, J. V. J. Biol. Chem 1984. $259,8753$.

2. Shaner. D. L.: Anderson, P. C.: Stidham, M. A. Plant Plysiol. 1984. 76,545

3. Gerwick. B. C.: Subermanian. V. I.: Loney-Gallant. V. I.: Chander. 
D. P. Pestic Sil 1990. 29.357

4. Shimizu. T.: Nakayama. I.: Nakao. T.: Nezu. Y.: Abe. H. J. Pestic Sici. 1994a. 19.59

5. Shimizu, T: Nakavama I: Wada N.: Nakao. T.: Abe. H. J. Pestic Sci. 1994b. 19.257.

6. Dugglebr. R. G.: Pang. S. S. J. Biochem. Mol. Biol. 2000. 33. 1

7. Singh. B.: Schmitt. G.: Lillis. M.: Hand. J. M.: Misra. R. Ptont Phvsiol. 1991. 97.657.

8. Chang. S. I.: Kang. M. K.: Choi. J. D.: Namgoong. S. K. Biochem. Bioplys. Res. Commm. 1997, 234, 549

9. Jung S. M.: Le. D. T: Yoon. S. S.: Yoon. M. Y.: Kinn. Y. T: Choi, I. D. Biochem. J. 2004, 383(1). 53

10. Yoon. T. Y.: Chung. S. M.: Chang. S. I.: Yoon. M. Y: Halnn. T. R.: Choi. J. D. Biochem. Bioply. Res. Commm. 2002. 293.433.

11. Le. D. T.: Yoon. M. Y.: Kim. Y. T.: Choi. J. D. J. Biochem. 2005. 138,35

12. Oh, K. J.: Park, E. J: Yoon. M. Y: Han. T. R: Choi. J. D. Biochem. Biophn Res. Conmm 2001, 282. 1237

13. Le. D. T: Yoon. M. Y: Kim. Y. T.: Choi. J. D. Biochent. Biophn: Res. Conmmin. 2003. 306. 1075.

14. Le. D. T: Yoon. M. Y: Kim. Y. T.: Choi. J. D. Biochintica et Bioplysica Acta 2005. 1749, 103.

15. Choi, K. J.: Pham, C. N.: Jung. H.; Han, S. H.; Choi, J. D.: Kim, J.: Yoon, M. Y. Bull. Korean Chem. Soc. 2007. 28. 1109.
16. Le. D. T.: Lee. H. S.: Chung. Y. T.: Yoon1. M. Y.: Choi. T. D. Bntl. Korean Chem. Soc. 2007. 28. 947.

17. Choi. K. J: Noh. K. M.: Choi. T. D.: Park. T. S.: Won. H. S.: Kim. J. R.: Kim. J. S.; Yoon. M. Y. Bull. Korean Chem. Soc. 2006, 27. 1697.

18. Chong. C. K.: Shin, H. J:- Chang. S. I.: Choi, J. D. Biochem Biophn Res. Conmmin 1999. 259. 136.

19. Pang. S. S.: Duggleby. R. G.: Guddat. L. W. J. M fol. Biol. 2002 317.249 .

20. Kim. J.: Beak. D. G: Kim, Y. T: Choi. J. D.; Yoon. M. Y Biochem. J. 2004, 384. 59 .

21. Karim. M; Shim, M. Y.: Kim. J: Choi. K. J.: Kim. J. R.: Choi, J D.: Yoon1. M. Y. Bull. Korem Chent Soc. 2006. 27. 549.

22. Perczel. A.: Hollosi. M.: Tusnady. G.: Fasman. G. D. Protein Eng 1991b. +. 669

23. Duggleby, R. G.: Pang. S. S.: Yu. H. Guddat, L. W. Eur. J. Biochem. 2003, 270. 2895

24. Chang, A. K.: Duggleby, R. G. Biochem. J. 1998, 333. 765.

25. Engel. S.: Vyamensky. M.: Vinogrador. M.: Berkovich. D.: BarIlan1. A.: Qimron. U.: Rosiansky. Y.: Barak. Z.: Chipman. D. J. Biol Chem. 2004. 279. 24803 .

26. Le. D. T.; Choi, J. D. Bull. Korean Chem. Soc. 2005, $26,916$.

27. Kim. J: Choi, J. D.: Kim, B. H.: Yoon, M. Y. Bull. Konam Chem. Soc. $2005,26,260$. 